A N N A L ES

UNIVERSITATIS MARIAE CURIE-SKŁODOWSKA

LUBLIN - POLONIA

VOL. LXII, 2

SECTIO G

2015

INETTA JĘDRASIK-JANKOWSKA

Niektóre regulacje prawne ubezpieczenia chorobowego, rentowego i wypadkowego a konstytucyjna zasada równości i sprawiedliwości

Selected Legal Regulations of Sickness Insurance, Pension Insurance and Accident Insurance in the Context of Constitutional Principle of Equality and Justice

\title{
UWAGI WSTĘPNE
}

Konstytucja Rzeczypospolitej Polskiej w art. 67 przyznaje obywatelom prawo do zabezpieczenia społecznego w razie niezdolności do pracy ze względu na chorobę lub inwalidztwo oraz po osiągnięciu wieku emerytalnego. To obywatelskie prawo oznacza obowiązek państwa przejęcia ryzyka zajścia wymienionych zdarzeń i stworzenia mechanizmu ochrony.

Realizacja tego obowiązku w odniesieniu do przeważającej grupy obywateli dokonuje się przez ubezpieczenie społeczne, czyli techniką zakładającą istnienie specjalnego funduszu tworzonego przy udziale osób zagrożonych określonym ryzykiem. $\mathrm{Z}$ funduszu tego $\mathrm{w}$ razie zajścia zdarzenia losowego zagrażającego bezpieczeństwu socjalnemu ubezpieczonego, tj. pozbawiającego go środków utrzymania, są udzielane świadczenia na zasadach odwzorowujących udział w tworzeniu tego funduszu.

Konstytucja w art. 67 wymienia trzy przyczyny, których zajście obliguje państwo do udzielania obywatelom ochrony. Są to: choroba, inwalidztwo i osiągnięcie wieku emerytalnego. Semantycznie rzecz ujmując, choroba i inwalidztwo to nazwy biologicznego stanu organizmu, natomiast wiek emerytalny to pojęcie prawne, czyli określony przez przepisy wiek pozwalający na odejście z rynku pracy, który ze stanem zdrowia może nie mieć nic wspólnego. Z niezdolnością do pracy mogłoby mieć natomiast określenie „na wypadek starości”, które też odnosi się do stanu organizmu człowieka i może być przyczyną niezdolności do zarobkowania. 
Nowoczesne społeczeństwa nie odwołują się już jednak do naturalnej utraty sił w miarę starzenia się organizmu ${ }^{1}$, ale udzielają ochrony po osiągnięciu wieku, który uznają za pozwalający na zakończenie działalności zawodowej i odpoczynek, a tym samym na zakończenie osiągania środków utrzymania własną pracą.

Z Konstytucji RP wynika zatem konieczność ochrony na wypadek niezdolności do pracy z powodu choroby lub inwalidztwa oraz ochrony z tytułu osiągnięcia wieku emerytalnego. Ochrona każdej z tych sytuacji wymaga nieco innych instrumentów prawnych. $Z$ tego względu ubezpieczenie społeczne realizowane jest odrębnie w odniesieniu do sytuacji osiągnięcia wieku emerytalnego i odrębnie w odniesieniu do niezdolności do pracy. Ochrona na wypadek niezdolności do pracy realizowana jest jednak nie według rodzaju biologicznej przyczyny (choroba, inwalidztwo), ale ze względu na rodzaj i zakres niezdolności do pracy spowodowanej chorobą lub inwalidztwem ${ }^{2}$. Ochrona ubezpieczeniowa jest więc różnicowana ze względu na rodzaj skutków zajścia biologicznej przyczyny, które mogą oznaczać albo tylko czasową (przejściową) niezdolność do pracy z powodu choroby lub kalectwa, albo długo trwającą (trwałą) niezdolność do pracy z powodu choroby lub kalectwa. Pierwszy rodzaj niezdolności do pracy jest przedmiotem ochrony realizowanej przez ubezpieczenie chorobowe, a drugi - przez ubezpieczenie rentowe.

Oba wyżej wymienione rodzaje niezdolności do pracy są też przedmiotem ochrony realizowanej przez ubezpieczenie wypadkowe. Wydzielenie tego ubezpieczenia nastąpiło ze względu na kwalifikację prawną choroby, kalectwa i śmierci, dokonaną z punktu widzenia okoliczności ich doznania w celu udzielenia ubezpieczonemu bardziej korzystnej ochrony. Wypadek przy pracy to zatem pojęcie prawne na oznaczenie choroby, kalectwa lub śmierci spowodowanych przyczyną zewnętrzną, która zadziałała w okolicznościach wykonywania pracy³. Zakwalifikowanie zdarzenia losowego jako „wypadek przy pracy” lub „, choroba zawodowa" oznacza bardziej korzystną ochronę udzielaną przez ubezpieczenie wypadkowe niezdolności do pracy będącej skutkiem choroby lub kalectwa (inwalidztwa) pozostających w związku z pracą.

Przedmiotem dalszych rozważań będzie ocena zasad działania tych trzech rodzajów ubezpieczenia z punktu widzenia przestrzegania konstytucyjnej zasady równości i sprawiedliwości. Ocenie zostaną poddane przede wszystkim reguły obejmowania ochroną ubezpieczeniową oraz uwarunkowania nabywania prawa do udzielanych świadczeń.

1 Nie przyjmuje się już domniemania niezdolności do pracy w związku z osiągnięciem wieku, bo niezdolność do pracy jest chroniona tylko do czasu osiągnięcia wieku emerytalnego.

2 W znaczeniu potocznym, ,inwalidztwo” to niesprawność, widoczne odstępstwo od normalnego stanu zdrowia.

3 Ustawowa definicja wypadku przy pracy określa przyczynę urazu lub śmierci i bardziej jest przydatna służbom bhp. 


\section{OBJECCIE UBEZPIECZENIEM CHOROBOWYM}

Przedmiotem ochrony przez ubezpieczenie chorobowe (treścią ryzyka) jest utrata zarobków spowodowana czasową niezdolnością do pracy wskutek choroby albo z powodu odosobnienia w związku z chorobą zakaźną, albo przebywania w zakładzie leczniczym w celu leczenia uzależnienia od alkoholu lub środków odurzających, a także wskutek poddania się niezbędnym badaniom lekarskim dla kandydatów na dawców komórek, tkanek i narządów.

W odróżnieniu od ubezpieczenia emerytalnego i rentowego ubezpieczenie chorobowe nie jest obowiązkowe dla wszystkich osób mających jakikolwiek tytuł wymieniony w art. 6 ustawy z dnia 17 października 1998 roku o systemie ubezpieczeń społecznych (dalej: u.s.u.s.). $\mathrm{Z}$ art. 11 tej ustawy wynika bowiem, że ustawodawca dokonał podziału wszystkich tytułów na trzy grupy, tj. na tytuły, które muszą być objęte ubezpieczeniem chorobowym, tytuły, które mogą być nim objęte i tytuły wyłączone $\mathrm{z}$ tego ubezpieczenia.

Ubezpieczenie chorobowe jest obowiązkowe tylko dla tytułu ,pracownik” (art. 6 ust. 1 pkt 1), ,członek rolniczych spółdzielni produkcyjnych” (art. 6 ust. 1 pkt 3) i „zastępcza służba wojskowa” (art. 6 ust. 1 pkt. 12). Dobrowolnie (na swój wniosek) do ubezpieczenia chorobowego mogą przystąpić osoby wykonujące pracę nakładczą (art. 6 ust. 1 pkt 2), osoby, które zawarły umowę zlecenia (art. 6 ust. 1 pkt 4), osoby prowadzące pozarolniczą działalność oraz osoby z nimi współpracujące (art. 6 ust. 1 pkt 5), osoby wykonujące odpłatnie pracę na podstawie skierowania do pracy w czasie odbywania kary pozbawienia wolności lub tymczasowego aresztowania (art. 6 ust. 1 pkt 8 ) oraz duchowni (art. 6 ust. 1 pkt 10). Pozostałe tytuły (wymienione w art. 6, 6a i 6b) zostały wyłączone $\mathrm{z}$ ubezpieczenia chorobowego, bowiem albo nie stwarzają sytuacji chronionej tym ubezpieczeniem $^{4}$, albo ryzyko jest zabezpieczone w inny sposób.

Przeprowadzony przez ustawodawcę w art. 11 u.s.u.s. podział tytułów na trzy grupy nie budzi zastrzeżeń i w zasadzie zastrzeżeń nie budzi też katalog tytułów zaliczonych do poszczególnych grup.

Jako kryterium zaliczenia tytułu do grupy obowiązkowo ubezpieczonych na wypadek choroby przyjęto nieuchronność zajścia ryzyka utraty zarobków w razie czasowej niezdolności do pracy. Ryzyko to w odniesieniu do tytułów z grupy dobrowolnego ubezpieczenia może, ale nie musi, zachodzić albo utrata jest mało odczuwalna. $Z$ tego względu ustawodawca decyzję co do poddania się ubezpieczeniu na wypadek utraty środków utrzymania w okresie czasowej niezdolności do pracy pozostawił samym zainteresowanym.

Jednakże ta decyzja nie zależy wyłącznie od powyższej oceny dokonanej przez osoby posiadające tytuł dobrowolnie objęty ubezpieczeniem chorobowym,

4 Osoby mające dany tytuł nie tracą w okresie choroby środków do życia. 
ale nadto od faktu obowiązkowego opłacania składki na ubezpieczenie emerytalne i rentowe $\mathrm{z}$ tego tytułu. Zakreślając krąg tytułów dobrowolnie objętych ubezpieczeniem chorobowym, ustawodawca nie tylko wymienił te tytuły, ale też użył sformułowania ,osoby objęte obowiązkowo ubezpieczeniami emerytalnymi i rentowymi wymienione w art. 6 ust. 1 pkt 1, 2, 4, 5, 8 i 10" (art. 11 ust. 2). To sformułowanie powoduje, że dobrowolne ubezpieczenie chorobowe zostało związane $\mathrm{z}$ faktem obowiązkowego ubezpieczenia emerytalnego i rentowego $\mathrm{z}$ danego tytułu i eliminuje $\mathrm{z}$ tego ubezpieczenia osoby mające inny tytuł do ubezpieczenia.

Ta regulacja wydaje się sprzeczna $\mathrm{z}$ istotą dobrowolności jako przeciwieństwa obowiązku. Dobrowolność w ubezpieczeniu społecznym oznacza pozostawienie adresatowi normy prawnej oceny co do zagrożenia danym ryzykiem i podjęcia decyzji w kwestii poddania się ochronie. Wiązanie dobrowolnego ubezpieczenia na wypadek czasowej niezdolności do pracy z faktem obowiązkowego opłacania składki na ubezpieczenie emerytalne i rentowe prowadzi do sytuacji, w której utrata dochodów z dwóch umów o pracę będzie chroniona, ale jeśli jeden z tych dochodów będzie uzyskiwany w ramach umowy zlecenia albo prowadzonej pozarolniczej działalności (zwolnionych z obowiązkowego ubezpieczenia emerytalnego i rentowego), to nie będzie mógł być objęty ochroną na wypadek jego nieuzyskania ze względu na chorobę. Wobec tego, że nie ma jakichkolwiek argumentów za takim rozwiązaniem, należy je uznać za naruszające zasadę równości i sprzeczne z ratio legis tej konstrukcji prawnej.

\section{INNE PRZEJAWY NIERÓWNOŚCI W UBEZPIECZENIU CHOROBOWYM}

W ustawie z dnia 25 czerwca 1999 roku o świadczeniach pieniężnych z ubezpieczenia społecznego w razie choroby i macierzyństwa, do których można byłoby mieć zastrzeżenia z punktu widzenia zasady równości i sprawiedliwości, należy wymienić w zasadzie tylko art. 4 i art. 62 ustawy.

Pierwszy z tych przepisów ustala długość okresu wyczekiwania w celu nabycia prawa do zasiłku chorobowego na 30 dni dla osób podlegających ubezpieczeniu chorobowemu obowiązkowo i na 90 dni dla ubezpieczonych dobrowolnie. Ratio legis okresu wyczekiwania to zabezpieczenie się ubezpieczyciela przed ryzykami, które wystąpiły przed objęciem ubezpieczeniem. Słuszne jest zatem wydłużenie tego okresu w odniesieniu do ubezpieczenia dobrowolnego, co potwierdził Trybunał Konstytucyjny w wyroku z dnia 16 listopada 2010 roku (P 86/08).

Wskazane wątpliwości można jednak mieć do treści ust. 3 tego artykułu, który zwalnia z przebycia okresu wyczekiwania osoby obowiązkowo ubezpieczone, jeśli mają wcześniejszy, co najmniej 10-letni okres obowiązkowego ubezpieczenia chorobowego. Osobom dobrowolnie ubezpieczonym nie uwzględnia się ani wcześniejszego 10-letniego okresu ubezpieczenia obowiązkowego, ani tak długiego okresu dobrowolnego ubezpieczenia chorobowego, chociaż nie ma tu jakichkolwiek argumentów za takim rozwiązaniem. Uwzględniając ratio legis przesłanki odstąpienia 
od wykazania okresu wyczekiwania (długi czas pozostawania w ubezpieczeniu), nie powinna mieć znaczenia okoliczność, czy składka była płacona obowiązkowo, czy dobrowolnie. Z drugiej strony należy zauważyć, że jeśli kryterium odstąpienia od okresu wyczekiwania ma być czas płacenia składki, to większą „wartość” ma wcześniejsze długoletnie dobrowolne płacenie tej składki niż przymusowe. Jak się więc wydaje, nie ma istotnych argumentów na odmienne ukształtowanie sytuacji prawnej osób ubezpieczonych w zależności od charakteru ubezpieczenia.

Naruszenia zasady równości ubezpieczonych można dopatrzyć się także w regulacji zawartej w art. 62 ustawy zasiłkowej. Przepis ten w ust. 1 zobowiązuje ubezpieczonego do dostarczenia płatnikowi zwolnienia lekarskiego w ciągu 7 dni od daty jego otrzymania, a w ust. 3 przewiduje za niedopełnienie tego obowiązku sankcje w postaci obniżenia wysokości zasiłku chorobowego od dnia następnego po upływie terminu do dnia dostarczenia zaświadczenia, chyba że niedostarczenie zaświadczenia nastąpiło z przyczyn niezależnych od ubezpieczonego. Krąg ubezpieczonych objętych tą sankcją jest jednak ograniczony do pracowników zatrudnionych u płatników, którzy zgłaszają do ubezpieczenia chorobowego powyżej 20 ubezpieczonych. Sankcja ta nie dotyczy zatem pracowników mniejszych zakładów pracy, członków rolniczych spółdzielni produkcyjnych i osób ubezpieczonych dobrowolnie. Brak widocznej ratio legis powyższej regulacji uzasadnia zarzut naruszenia zasady równości ${ }^{5}$.

Prima facie naruszenia zasady równości i sprawiedliwości można dopatrywać się także w regulacji zawartej w art. 46 ustawy zasiłkowej. Przepis ten ustala, że podstawa wymiaru zasiłku chorobowego przysługującego za okres niezdolności do pracy po ustaniu tytułu ubezpieczenia chorobowego nie może być wyższa niż kwota wynosząca $100 \%$ przeciętnego wynagrodzenia. Przyjęte w art. 46 ustawy zasiłkowej rozwiązanie uzależnia wysokość zasiłku po ustaniu tytułu od wysokości wcześniejszych zarobków, ale tylko do pewnej granicy. W rezultacie część uprawnionych ma prawo do zasiłku chorobowego na zasadach ubezpieczeniowych (wymiar według wcześniejszych zarobków), ale ubezpieczeni płacący składkę od zarobków wyższych niż przeciętne wynagrodzenie otrzymają świadczenie w jednakowej kwocie ( $80 \%$ przeciętnego wynagrodzenia), co wskazuje na zasadę zaopatrzeniową.

Niemniej należy zgodzić się z koncepcją ograniczonej podstawy wymiaru zasiłku chorobowego za czas niezdolności po ustaniu tytułu. Jest to uzasadnione odmiennością chronionego ryzyka. O ile bowiem przedmiotem ochrony w czasie trwania ubezpieczenia chorobowego jest utrata dochodów z powodu czasowej niezdolności do pracy, o tyle ratio legis ochrony po ustaniu ubezpieczenia to zapewnienie środków utrzymania w czasie trwania spowodowanej stanem zdrowia przeszkody w poszukiwaniu nowego zatrudnienia.

5 Przepis ust. 3 przestanie obowiązywać 1 stycznia 2016 roku. 
Treścią ryzyka nie jest zatem fakt utraty źródła dochodów z powodu choroby, ale spowodowana chorobą przeszkoda w szukaniu nowego źródła dochodów. Odmienny charakter ryzyka uzasadnia odmienne warunki ochrony. Świadczenie nie musi się zatem odnosić do rozmiaru utraconego zarobku. Można przeto przyjąć, że warunki ochrony polegające na odwzorowaniu poprzednich zarobków, ale tylko do określonej granicy (100\% przeciętnego wynagrodzenia), nie naruszają zasady równości.

\section{OGRANICZENIA OCHRONY Z TYTUŁU WYPADKU PRZY PRACY}

Ochrona udzielana z tytułu wypadku przy pracy obejmuje te same rodzaje ryzyka, które chroni ubezpieczenie chorobowe i ubezpieczenie rentowe, ale ich cechą jest związek z wykonywaniem pracy. Cecha związku z pracą oznacza powiązanie czasowej i trwałej niezdolności do pracy z działalnością, która może być potencjalnym zagrożeniem dla życia lub zdrowia człowieka. Taka niezdolność jest chroniona przez ubezpieczenie wypadkowe.

Konstrukcja prawna tej ochrony wynika z literalnej treści art. 12 ustawy z dnia 13 października 1998 roku o systemie ubezpieczeń społecznych ${ }^{6}$. Przepis ten w ust. 1 stanowi, że „obowiązkowo ubezpieczeniu wypadkowemu podlegają osoby podlegające ubezpieczeniu emerytalnemu i rentowemu", a w ust. 2 enumeratywnie wylicza osoby (tytuły) wymienione w art. 6 ust. 1 u.s.u.s., które podlegając ubezpieczeniu emerytalnemu i rentowemu, nie podlegają ubezpieczeniu wypadkowemu.

Zestawienie treści art. 12 ust. $1 \mathrm{z}$ treścią ust. 2 tego przepisu uzasadnia twierdzenie, że ustawodawca w ust. 1 odsyła generalnie do katalogu tytułów podlegających obowiązkowi ubezpieczenia emerytalnego i rentowego zawartego $\mathrm{w}$ art. 6 ust. 1, a w ust. 2 wyłącza z tego obowiązku te tytuły, które nie wiążą się z jakąkolwiek działalnością, a więc nie występuje zagrożenie doznania urazu lub śmierci w związku z tą działalnością.

Powiązanie art. $12 \mathrm{i}$ art. 6 polega na technicznym wykorzystaniu katalogu tytułów podlegających obowiązkowi ubezpieczenia emerytalnego i rentowego, które to tytuły, dla celów ubezpieczenia wypadkowego, ustawodawca podzielił na dwie grupy, tj. tytuły objęte obowiązkowo ubezpieczeniem wypadkowym i tytuły wyłączone z tego ubezpieczenia. Podział ten oznacza, że objęte obowiązkiem ubezpieczenia wypadkowego zostały osoby ,podlegające ubezpieczeniu emerytalnemu i rentowemu", które nie zostały wyłączone z tego ubezpieczenia przez art. 12 ust. 2.

6 Ustawa z dnia 13 października 1998 roku o systemie ubezpieczeń społecznych (Dz.U. z 2015 roku, poz. 121). 
W języku polskim „podlegać” to m.in. „być poddanym czemuś” albo „być tym, którego coś dotyczy”. „Powinność” to inaczej „obowiązek”. „Podlegać ubezpieczeniu" to mieć powinność (obowiązek), która powstaje z mocy przepisu i wiąże się z posiadaniem tytułu. Inaczej mówiąc, powinność jest albo jej nie ma. Jednakże ta powinność może być w określonych okolicznościach (z mocy przepisu szczególnego) zawieszona. Takim przepisem zawieszającym obowiązek ubezpieczenia emerytalnego i rentowego w sytuacji posiadania kilku tytułów jest art. 9 u.s.u.s.

W odniesieniu do ubezpieczenia wypadkowego brak analogicznego przepisu. Oznacza to, że obowiązek ubezpieczenia wypadkowego z danego tytułu nie może zostać zawieszony w sytuacji posiadania więcej niż jednego tytułu z grupy pierwszej, tj. objętych obowiązkiem ubezpieczenia wypadkowego. W efekcie podleganie ubezpieczeniu wypadkowemu dotyczy wszystkich tytułów wymienionych w katalogu art. 6 ust. 1 u.s.u.s., które nie zostały wyłączone z tego ubezpieczenia przez art. 12 ust. 2 ustawy bez dalszej możliwości wyłączenia ochrony w razie zbiegu tytułów.

W praktyce organów rentowych stosowana jest jednak interpretacja ujmująca powiązanie art. $12 \mathrm{z}$ art. 6 ust. 1 nie jako odesłanie do katalogu tytułów mających powinność (obowiązek) ubezpieczenia emerytalnego i rentowego, ale jako powiązanie obowiązku ubezpieczenia wypadkowego z faktycznie realizowanym obowiązkiem ubezpieczenia emerytalnego i rentowego9. Określenie „podlegające” rozumie się więc jako „płacące składkę na ubezpieczenie emerytalne i rentowe"10.

Stosowana przez ZUS interpretacja wyprowadzana jest z treści art. 6 ust. 1 ustawy systemowej, zgodnie z którym osoby posiadające tytuł wskazany w tym przepisie podlegają obowiązkowo ubezpieczeniu emerytalnemu i rentowemu, ale z zastrzeżeniem m.in. art. 9 ustawy, co oznacza, że obowiązek ubezpieczenia emerytalnego i rentowego mają tylko te tytuły, o których mowa w art. 6 ust. 1, które na mocy art. 9 nie zostały $\mathrm{z}$ tego obowiązku zwolnione na czas zbiegu tytułów. W tym ujęciu zwolnienie z obowiązku ubezpieczenia emerytalnego i rentowego jest też zwolnieniem z obowiązku ubezpieczenia wypadkowego.

Powyższa interpretacja wywołuje zarzut sprzeczności z konstrukcją prawną czterech niezależnych rodzajów ubezpieczenia społecznego, tj. z czterema odrębnymi składkami i odmiennymi zasadami podlegania poszczególnym rodzajom ubezpieczenia.

7 Mały słownik języka polskiego, pod red. S. Skorupki, H. Auderskiej, Z. Łempickiej, Warszawa 1968, s. 580.

8 Zob. Stownik frazeologiczny języka polskiego, Warszawa 1989.

9 Zob. Komentarz do ustawy o systemie ubezpieczeń społecznych, pod red. B. Gudowskiej, J. Strusińskiej-Żukowskiej, Warszawa 2011, s. 280-283.

10 Także dobrowolnie, co w praktyce ZUS oznacza obowiązkową ochronę wypadkową, co łagodzi konsekwencje złej interpretacji, ale nie usuwa problemu braku ochrony osób, które skorzystały ze zwolnienia z obowiązku ubezpieczenia emerytalnego i rentowego. 
Z legislacyjnego punktu widzenia stosowanie formuły „z zastrzeżeniem...” ma sens wówczas, gdy zastosowanie powoływanego przepisu jest niezbędne dla prawidłowego działania przepisu głównego i bez tego zastrzeżenia przepis główny nie zostałby prawidłowo zastosowany ${ }^{11}$. Taka sytuacja nie zachodzi w odniesieniu do art. 6 ust. 1, którego zadaniem jest wskazanie katalogu tytułów objętych obowiązkiem ubezpieczenia, natomiast art. 9 reguluje sytuację posiadania kilku tytułów objętych obowiązkiem ubezpieczenia emerytalnego i rentowego. Oba przepisy działają zatem niezależnie od siebie. Jeden wskazuje, kto ma obowiązek ubezpieczenia, a drugi - co dzieje się, jeśli zbiegają się dwa takie obowiązki, czyli reguluje zupełnie odrębną sytuację. Efekt objęcia obowiązkiem tylko jednego z posiadanych tytułów jest osiągany bez konieczności dokonania zastrzeżenia zastosowania przepisu o zbiegu tytułów (art. 9).

Powiązanie obu przepisów zmienia jednak charakter art. 6 ust. 1, który przestaje w ten sposób spełniać rolę katalogu tytułów do obowiązkowego ubezpieczenia emerytalnego i rentowego. Inaczej mówiąc, należałoby przyjąć, że art. 6 ust. 1 nie jest katalogiem tytułów, z którymi łączy się obowiązek ubezpieczenia emerytalnego i rentowego, ale przepisem sugerującym, że obowiązek ubezpieczenia wiąże się nie z posiadanym tytułem, tylko z opłacaniem składki, co jest sprzeczne z zasadami wynikającymi z art. 67 Konstytucji RP. Z Konstytucji wynika bowiem, że państwo ma obowiązek zorganizowania systemu ubezpieczenia społecznego i wskazania osób objętych tym systemem. $\mathrm{Z}$ tego powodu odesłanie do art. 6 ust. 1 musi oznaczać odesłanie do katalogu tytułów, a nie do osób płacących składkę. Odwołanie się przez art. 6 ust. 1 u.s.u.s. do art. 9 tej ustawy należy zatem uznać za błąd natury legislacyjnej powodujący istotne niekorzystne skutki w zakresie ochrony w razie wypadku przy pracy.

Konsekwencją użycia formuły „z zastrzeżeniem art. 9" jest wykładnia, że art. 12 ust. 1 odwołuje się do realizowanego faktycznie obowiązku ubezpieczenia emerytalnego i rentowego, a nie że ustanawia określoną sytuację prawną dla danego tytułu. Dochodzi zatem do pozbawienia ubezpieczenia wypadkowego nie tylko tytułów wyłączonych przez art. 12 ust. 2, ale także tych, które ze względu na zbieg tytułów zostały zwolnione z obowiązkowego ubezpieczenia emerytalnego i rentowego. W efekcie dochodzi do sytuacji, w której ochrona wypadkowa prowadzonej działalności uzależniona jest nie od istnienia zagrożenia, ale od jednoczesnego braku zwolnienia danego tytułu z opłacania obowiązkowej składki na ubezpieczenie emerytalne i rentowe. Jest to jednak wyłączenie poza wolą ustawodawcy wyrażoną $\mathrm{w}$ ratio legis ubezpieczenia wypadkowego.

11 Prawidłowo formułę ,z zastrzeżeniem...” użył ustawodawca np. w art. 6 ust. 2a u.s.u.s., obejmującym ubezpieczeniem osoby w nim wymienione do czasu osiągnięcia przez nie 25 lat okresów ubezpieczenia, z zastrzeżeniem zastosowania przepisu, który w okresie przejściowym modyfikuje długość tego stażu. Bez zastrzeżenia zastosowania przepisu ,przejściowego” przepis art. 6 ust. 2a u.s.u.s. miałby inną treść. Taka sytuacja nie zachodzi w przypadku art. 6 ust. 1 u.s.u.s. 
Powiązanie ubezpieczenia wypadkowego z obowiązkowym ubezpieczeniem emerytalnym i rentowym przyjmuje drastyczny wyraz $\mathrm{w}$ odniesieniu do studentów wykonujących umowę zlecenia, zwolnioną z obowiązku ubezpieczenia emerytalnego i rentowego, bowiem zwolnienie to przełoży się nie tylko na brak ochrony w razie zdarzeń kwalifikowanych jako „z ogólnego stanu zdrowia”, ale także pozbawi szczególnej ochrony w razie niezdolności do pracy lub utraty żywiciela, spowodowanych wypadkiem przy wykonywaniu umowy zlecenia, naruszając tym samym zasadę równego traktowania osób zagrożonych doznaniem szkody na osobie w związku z działalnością zawodową.

Jak się wydaje, , ,całe zło" bierze się z błędu legislacyjnego w treści art. 6 ust. 1 u.s.u.s. Ten błąd legislacyjny doprowadził do interpretacji art. 12 ustawy systemowej może zgodnej z literalnym brzmieniem źle sformułowanego przepisu, ale za to niezgodnej z intencją ustawodawcy i z naruszeniem konstytucyjnej zasady udzielania takiej samej ochrony w takiej samej sytuacji faktycznej. Wystarczyłoby zatem usunąć z treści art. 6 ust. 1 ustawy o systemie słowa „,z zastrzeżeniem art. 9"'12, aby art. 12 tej ustawy działał zgodnie z intencją ustawodawcy i Konstytucją. W ujęciu art. 12 ubezpieczenie wypadkowe jest bowiem albo obowiązkowe (ust. 1), albo wyłączone (ust. 2), a kryterium podziału (objęcia ochroną) jest wyłącznie zagrożenie ryzykiem wypadku przy pracy.

Obowiązek ubezpieczenia wypadkowego nie może mieć charakteru relatywnego, zależnego od innych czynników niż zagrożenie zdrowia lub życia, a w szczególności wpływu na tę ochronę nie może mieć zwolnienie danego tytułu z obowiązku ubezpieczenia emerytalnego i rentowego. Zwolnienie to nie oznacza bowiem zaprzestania działalności i braku zagrożenia. Sytuacja, w której ryzyko zaszło, a wyłączona była ochrona, nie jest zatem zgodna z Konstytucją.

\section{NIERÓWNOŚĆ PRAWNA W UBEZPIECZENIU RENTOWYM}

Zasady działania ubezpieczenia rentowego dość rzadko były przedmiotem zaskarżania do Trybunału Konstytucyjnego. Za regulację łamiącą zasadę równości można jednak uznać ustanowione reguły dotyczące zamiany renty na emeryturę. Prowadzi ona bowiem do podzielenia rencistów na trzy grupy. Na gruncie obecnie obowiązujących przepisów zamiana renty na emeryturę jest dokonywana z urzędu. Jest to uzasadnione, gdyż renta jest świadczeniem ex definitione na wypadek niezdolności do pracy przed osiągnięciem wieku emerytalnego. Zamiana renty na emeryturę dotyczy wszystkich rencistów, którzy osiągnęli wiek emerytalny, nawet jeśli nie mają wymaganego stażu ubezpieczeniowego ${ }^{13}$, co w odniesieniu do

12 Analogiczne uwagi należy odnosić do zastrzeżenia stosowania art. 8 ust. 2a.

13 Dotychczas nabycie prawa do renty oznaczało możliwość jej dożywotniego pobierania, jeśli rencista nie spełniał warunków albo nie wystąpił o zamianę na emeryturę. 
osób urodzonych przed 1 stycznia 1949 roku mogło budzić teoretyczne zastrzeżenia, ale z praktycznego punktu widzenia kwestia ta miała niewielkie znaczenie ${ }^{14}$.

Zgodnie z art. 21 ust. 1 ustawy z dnia 17 grudnia 1998 roku o emeryturach i rentach $z$ ubezpieczenia społecznego ${ }^{15}$ podstawę wymiaru emerytury dla osoby, która miała wcześniej ustalone prawo do renty z tytułu niezdolności do pracy może stanowić: 1) podstawa wymiaru renty - w wysokości uwzględniającej rewaloryzację oraz wszystkie kolejne waloryzacje przypadające w okresie następującym po ustaleniu prawa do renty (art. 21 ust. 1 pkt 1), albo 2) podstawa ustalona na nowo według reguł dotyczących ustalania podstawy wymiaru emerytur i rent (art. 21 ust. 1 pkt 2). Ten alternatywny sposób wyliczenia podstawy ma na celu umożliwienie zainteresowanemu wyboru korzystniejszego rozwiązania. Organ rentowy powinien zatem wyliczyć emeryturę według obu sposobów i przyjąć bardziej korzystny ${ }^{16}$.

Formuła wymiaru emerytury w systemie zdefiniowanego świadczenia, uwzględniająca kwotę stałą na dzień ustalenia prawa do danego świadczenia, powoduje, że im później świadczenie jest ustalone, tym wyższa jest kwota stała, dlatego emerytura jako świadczenie później ustalane powinna być wyższa od renty, nawet przy tej samej podstawie wymiaru świadczenia. W praktyce jednak organ rentowy, w sytuacji gdy do wymiaru emerytury była przyjmowana podstawa wymiaru renty ${ }^{17}$, stosował także tę samą kwotę stałą, co powodowało, że oba świadczenia były takie same. Praktykę tę zniosła uchwała Sądu Najwyższego z dnia 20 października 2002 roku $^{18}$.

Wynikająca z uchwały Sądu Najwyższego zasada działała tylko do dnia 1 lipca 2004 roku. $Z$ tą datą zaczęly bowiem obowiązywać ust. 3 i 4 dodane do art. 53 ustawy emerytalnej. $Z$ przepisów tych wynika, że przy zamianie renty na emeryturę kwotę stałą z daty nabycia prawa do emerytury można zastosować tylko w odniesieniu do rencistów, którzy: 1) podstawę wymiaru emerytury mają wyliczoną od nowa albo 2) w okresie pobierania renty przepracowali co najmniej 30 miesięcy. Pozostałym rencistom emerytura zostanie wyliczona według danych na dzień nabycia prawa do renty i zwaloryzowana na dzień nabycia prawa do emerytury ${ }^{19}$.

Metoda wynikająca $z$ art. 53 ust. 3 i 4 ustawy emerytalnej jest sprzeczna z zasadą, że wysokość emerytury ustala się na dzień spełnienia warunków do nabycia tego prawa (albo na późniejszy dzień złożenia wniosku) oraz że kwota stała musi być jed-

14 Dotyczyła bowiem ograniczonego kręgu osób.

15 Ustawa z dnia 17 grudnia 1998 roku o emeryturach i rentach z ubezpieczenia społecznego (Dz.U z 2015 roku, poz. 748).

16 Obowiązek organu rentowego działania na korzyść świadczeniobiorcy potwierdził Sąd Najwyższy w wyroku z dnia 24 stycznia 1996 roku, II URN 60/95, OSNAPiUS 1997, nr 4, poz. 53.

$17 \mathrm{Z}$ tego powodu, że nie można było wskazać odpowiedniego okresu zatrudnienia przyjmowanego do wyliczenia podstawy.

18 Uchwała Sądu Najwyższego z dnia 20 października 2002 roku, III UZP 7/02, OSNP 2003, nr 2, poz. 42.

19 Będzie to w praktyce ta sama kwota. 
nakowa dla wszystkich przechodzących na emeryturę w tym samym okresie. W efekcie dochodzi do stosowania trzech różnych sposobów wymiaru emerytury po rencie sprowadzających się do odmiennego połączenia kwoty stałej (C) i podstawy wymiaru świadczenia (P), które mogą zostać powiązane następująco: $\mathrm{C} 2+\mathrm{P} 2, \mathrm{C} 2+\mathrm{P} 1, \mathrm{C} 1+\mathrm{P} 1$.

Sposób pierwszy zostanie zastosowany w sytuacji, w której możliwe będzie obliczenie nowej podstawy wymiaru emerytury ${ }^{20}$. Drugie połączenie będzie zastosowane, gdy przyjęta będzie ta sama podstawa, którą zastosowano do wyliczenia renty, ale rencista w okresie pobierania renty podlegał ubezpieczeniu społecznemu lub emerytalnemu i rentowemu przez co najmniej 30 miesięcy. Formuła: poprzednia kwota stała $\left(\mathrm{C}_{1}\right)$ i poprzednia podstawa $\left(\mathrm{P}_{1}\right)$ będą zastosowane w pozostałych przypadkach.

Mimo zróżnicowania rencistów ze względu na datę przejścia na rentę i niemający żadnego uzasadnienia warunek 30-miesięcznego ubezpieczenia w okresie pobierania renty, Trybunał Konstytucyjny w wyroku z dnia 24 kwietnia 2006 roku (P 9/05) uznał, że ust. 3 i 4 art. 53 ustawy emerytalnej nie są niezgodne z Konstytucją.

Za naruszający zasadę równości należy też uznać art. 5 ust. 4 ustawy emerytalnej, który stanowi, że ubezpieczonym będącym płatnikami składek na własne ubezpieczenie oraz osobom z nimi współpracującym, przy ustalaniu prawa do emerytury lub renty nie uwzględnia się okresu, za który nie zostały opłacone składki. Przepis ten budzi zastrzeżenia tylko w odniesieniu do prawa do renty, bowiem nabycie prawa do emerytury nie zależy już od stażu ubezpieczeniowego. Nieopłacenie składki emerytalnej w jakimś okresie trwania obowiązku ubezpieczenia może co najwyżej wpłynąć na kwotę świadczenia ustalanego według sumy zgromadzonych składek, ale nie na prawo do emerytury.

Inaczej jest $\mathrm{w}$ odniesieniu do renty $\mathrm{z}$ tytułu niezdolności do pracy lub renty rodzinnej, gdzie efekt nienabycia prawa jest możliwy, ponieważ przepisy wymagają tu spełnienia dwóch warunków: czasu zajścia zdarzenia i posiadania wymaganego stażu ubezpieczeniowego. Nieuwzględnienie wskazanego okresu może oznaczać niespełnienie przynajmniej jednego z tych warunków.

W ujęciu art. 5 ust. 4 ustawy emerytalnej ubezpieczony prowadzący pozarolniczą działalność, pozostający w ubezpieczeniu kilkanaście lat, który stał się niezdolny do pracy albo zmarł w okresie, kiedy składka nie była zapłacona, nie spełni warunku czasu zajścia zdarzenia i tym samym nie powstanie prawo ani do renty dla ubezpieczonego, ani do renty rodzinnej dla osób, które utraciły żywiciela. Nieuwzględnienie wskazanego okresu może też oznaczać niespełnienie warunku posiadania minimalnego stażu ubezpieczeniowego. Należy jednak zauważyć, że w odniesieniu do pozostałych grup ubezpieczonych w analogicznej sytuacji prawo do obu świadczeń powstanie.

20 Dotyczy to sytuacji, gdy między nabyciem prawa do renty a wiekiem emerytalnym nie upłynęło więcej niż 10 lat. 
Ratio legis powyższej regulacji zasadza się na koncepcji „winy” osoby samodzielnie płacącej składkę w jej nieuiszczeniu, chociaż nie można jej przypisać osobie współpracującej, dla której płatnikiem jest osoba prowadząca działalność. Jakkolwiek prima facie kwestia „winy” różnicuje sytuację osoby samodzielnie opłacającej składkę na swoje ubezpieczenie, to jednak regulacja wynikająca $\mathrm{z}$ art. 5 ust. 4 ustawy emerytalnej narusza zasadę równości ubezpieczonych rozumianą jako równy dostęp do ubezpieczenia w ujęciu art. 67 ust. 1 Konstytucji. Należy zauważyć, że art. 67 ust. 1 Konstytucji nakłada na państwo obowiązek przejęcia ryzyka braku środków utrzymania w określonych sytuacjach życiowych obywateli. Obowiązek ten państwo realizuje, włączając do systemu wszystkich obywateli, przy czym przejęcie ryzyka może nastąpić na zasadzie ubezpieczeniowej, zaopatrzeniowej albo pomocowej.

Zasada ubezpieczeniowa sprowadza się do utworzenia specjalnego funduszu, na który składają się wpłaty (składki) osób ubezpieczonych, co oznacza, że składka należy się za udzielaną przez państwo ochronę (przejęcie ryzyka). Składka na ubezpieczenie społeczne ma zatem charakter wtórny do udzielanej ochrony. Relacja między powstaniem stosunku ubezpieczenia społecznego a składką jest odmienna niż w ubezpieczeniu cywilnym (gospodarczym), gdzie uprzednie zapłacenie składki warunkuje powstanie stosunku ubezpieczenia i odpowiedzialność ubezpieczyciela. Stosunek ubezpieczenia społecznego powstaje natomiast ex lege i jest powiązany z tytułem objętym obowiązkiem ubezpieczenia emerytalnego i rentowego ${ }^{21}$ niezależnie od faktu opłacenia składki.

W ubezpieczeniu społecznym składka nie warunkuje objęcia systemem ${ }^{22}$. Rola składki sprowadza się do określenia rozmiaru udziału w tworzeniu funduszu. Od rozmiaru tego udziału może być też uzależniony rozmiar korzystania z funduszu (wymiar świadczenia) jakkolwiek mogą być również przyjęte inne kryteria wymiaru (np. staż ubezpieczeniowy).

Ochrona ubezpieczeniowa zaczyna się zatem wraz z uzyskaniem tytułu do obowiązkowego ubezpieczenia i trwa jeszcze 18 miesięcy po ustaniu tego tytułu ${ }^{23}$. Wszystkie zdarzenia będące ryzykiem ubezpieczeniowym, które zajdą w okresie trwania ubezpieczenia, spełnią warunek czasu zajścia zdarzenia i posiadania stażu ubezpieczeniowego. Niezapłacenie składki nie powoduje wyłączenia ochrony ubezpieczeniowej. Innymi słowy, zajście ryzyka w okresie, kiedy składka nie została zapłacona, nie może pozbawić prawa do ochrony ubezpieczeniowej.

$\mathrm{Z}$ założeń teoretycznych ochrony udzielanej na podstawie art. 67 Konstytucji nie wynika też możliwość wyłączenia okresu trwania ubezpieczenia, za który nie opłacono składki, ze stażu ubezpieczeniowego warunkującego wymiar świad-

\footnotetext{
${ }^{21}$ Wymienia je art. 6 ust. 1 i 2 oraz art. 6 a i 6 b u.s.u.s.

22 Składka jest płacona „z dołu”, czyli w następnym miesiącu za poprzedni miesiąc.

23 Mówiąc obrazowo, nadal nad daną osobą trzymany jest parasol ochronny.
} 
czeń. Płatnik (ubezpieczony), który nie spełnił obowiązku uiszczenia opłaty za udzielaną ochronę, powinien zostać metodami administracyjnymi przymuszony do jego realizacji. Organ rentowy dysponuje tu całym szeregiem odpowiednich instrumentów prawnych. Skutki niewykorzystania tych instrumentów (niewłaściwego działania organów państwa) nie mogą być przerzucane na ubezpieczonego i jego rodzinę, powodując np. nienabycie prawa do renty rodzinnej. Biorąc pod uwagę, że powyższy problem nie powstaje w odniesieniu do pozostałych ubezpieczonych, należy uznać, że przepis art. 5 ust. 4 ustawy emerytalnej, mający zastosowanie tylko do osób samodzielnie zarobkujących, narusza konstytucyjną zasadę równości.

\section{PODSUMOWANIE}

Jakkolwiek rozwiązania prawne powodujące naruszenie zasady równości występujące w omawianych trzech rodzajach ubezpieczenia stanowią istotny problem, to równie duży problem stwarzają regulacje nie tyle nierówne czy niesprawiedliwe, co nielogiczne lub w niewłaściwy sposób rozwiązujące daną sytuację. W szczególności można tu wymienić: przepisy dotyczące utraty prawa do zasiłku chorobowego; regulację sytuacji poszkodowanego winnego spowodowania wypadku przy pracy, którego pozbawia się nie tylko wyższych świadczeń, ale często jakiejkolwiek ochrony; zdefiniowanie wypadku przy pracy dla potrzeb służby bezpieczeństwa i higieny pracy, a nie prawa do świadczeń z ubezpieczenia społecznego; niewłaściwe rozwiązanie kwestii ujawnienia zwolnienia lekarskiego, co wbrew logice i istocie zwolnienia lekarskiego jest możliwe nawet 6 miesięcy od ostatniego dnia zwolnienia itp.

Należy zauważyć, że istnienie tego typu nieprawidłowości w ustawach z ubezpieczenia społecznego może specjalnie nie dziwić ze względu na duży stopień skomplikowania występujących konstrukcji prawnych. Zastanawiający jest jednak brak reakcji ustawodawcy na wskazywane od lat w literaturze powyższe błędy. Dotyczy to także kwestii uregulowania i realizacji obowiązku ubezpieczenia chorobowego i wypadkowego.

\section{BIBLIOGRAFIA}

Komentarz do ustawy o systemie ubezpieczeń społecznych, pod red. B. Gudowskiej, J. StrusińskiejŻukowskiej, Warszawa 2011.

Mały słownik języka polskiego, pod red. S. Skorupki, H. Auderskiej, Z. Łempickiej, Warszawa 1968. Stownik frazeologiczny języka polskiego, Warszawa 1989.

Uchwała Sądu Najwyższego z dnia 20 października 2002 roku, III UZP 7/02, OSNP 2003, nr 2, poz. 42.

Wyrok Sądu Najwyższego z dnia 24 stycznia 1996 roku, II URN 60/95, OSNAPiUS 1997, nr 4, poz. 53. 


\section{SUMMARY}

Constitution of Republic of Poland in the article 67 grants citizens access to social security whenever incapacitated for work by reason of sickness or invalidism as well as having attained retirement age. The scope and forms of social security shall be specified by statute. Statutes which regulate basic issues of social insurance law (sickness insurance, pension insurance, accident insurance) not always obey constitutional principle of equality and justice. In the article author presents selected legal provisions which violate this rule.

Keywords: Constitution; sickness insurance; pension insurance; accident insurance; principle of equality and justice 